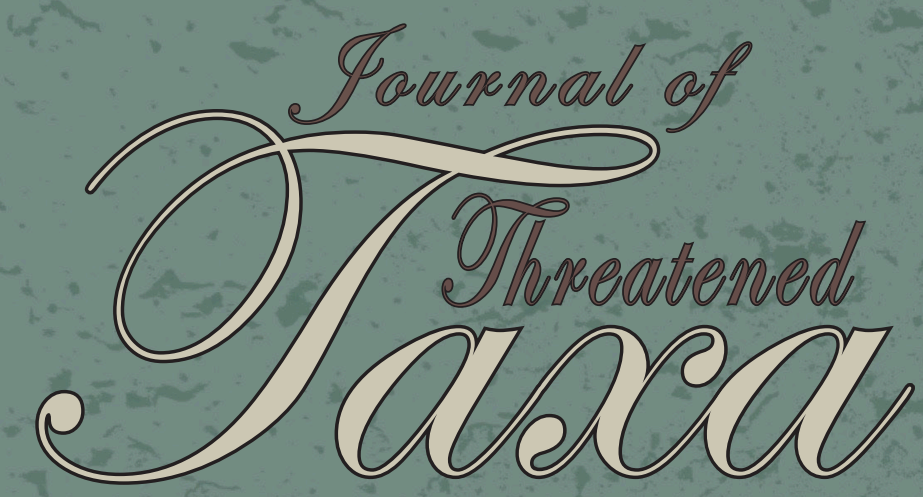

Building evidence for conservation globally
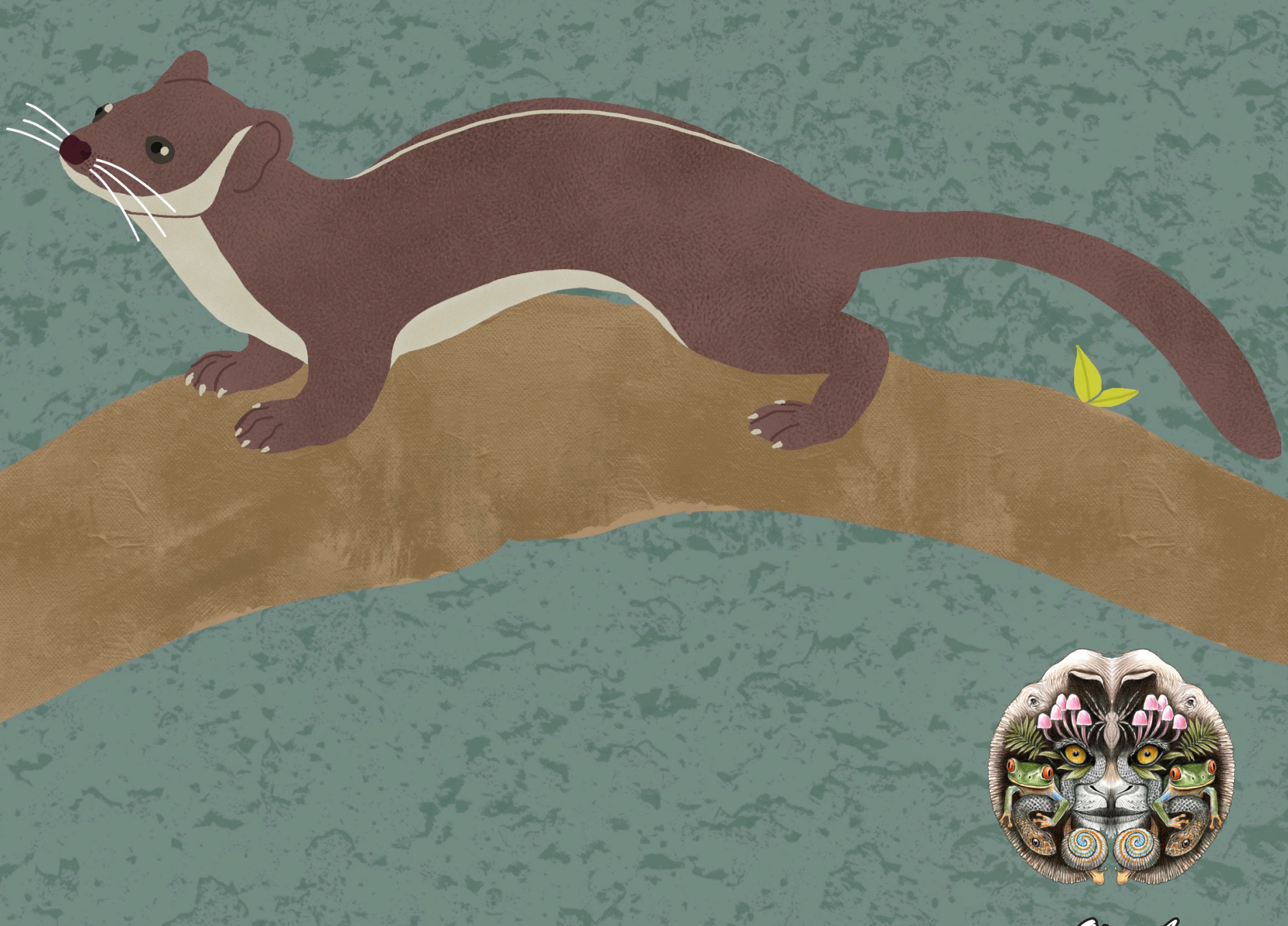

Qpecosecess

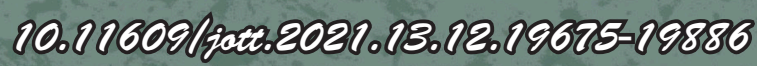
cocosurthreatecredtassararg

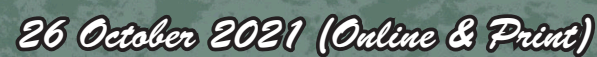

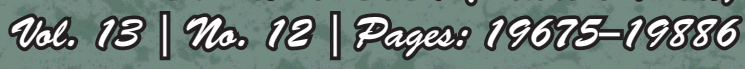




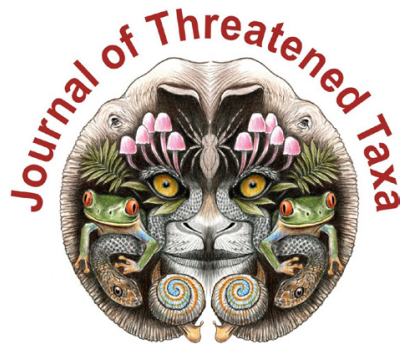

ISSN 0974-7907 (Online); ISSN $0974-7893$ (Print)

Publisher

Host

Wildlife Information Liaison Development Society

www.wild.zooreach.org

Zoo Outreach Organization www.zooreach.org

No. 12, Thiruvannamalai Nagar, Saravanampatti - Kalapatti Road, Saravanampatti, Coimbatore, Tamil Nadu 641035, India

Ph: +91 9385339863 | www.threatenedtaxa.org

Email: sanjay@threatenedtaxa.org

EDITORS

\section{Founder \& Chief Editor}

Dr. Sanjay Molur

Wildlife Information Liaison Development (WILD) Society \& Zoo Outreach Organization (ZOO)

12 Thiruvannamalai Nagar, Saravanampatti, Coimbatore, Tamil Nadu 641035, India

\section{Deputy Chief Edito}

Dr. Neelesh Dahanukar

Noida, Uttar Pradesh, India

\section{Managing Editor}

Mr. B. Ravichandran, WILD/ZOO, Coimbatore, India

\section{Associate Editors}

Dr. Mandar Paingankar, Government Science College Gadchiroli, Maharashtra 442605, India Dr. Ulrike Streicher, Wildlife Veterinarian, Eugene, Oregon, USA

Ms. Priyanka Iyer, ZOO/WILD, Coimbatore, Tamil Nadu 641035, India

Dr. B. A. Daniel, $200 /$ WIID, Coimbatore, Tamil Nadu 641035, India

\section{Editorial Board}

Dr. Russel Mittermeie

Executive Vice Chair, Conservation International, Arlington, Virginia 22202, USA

\section{Prof. Mewa Singh Ph.D., FASc, FNA, FNASc, FNAPsy}

Ramanna Fellow and Life-Long Distinguished Professor, Biopsychology Laboratory, and Institute of Excellence, University of Mysore, Mysuru, Karnataka 570006, India; Honorary Professor, Jawaharlal Nehru Centre for Advanced Scientific Research, Bangalore; and Adjunct Professor, National Institute of Advanced Studies, Bangalore

\section{Stephen D. Nash}

Scientific Illustrator, Conservation International, Dept. of Anatomical Sciences, Health Sciences Center, T-8, Room 045, Stony Brook University, Stony Brook, NY 11794-8081, USA

\section{Dr. Fred Pluthero}

Toronto, Canada

\section{Dr. Priya Davidar}

Sigur Nature Trust, Chadapatti, Mavinhalla PO, Nilgiris, Tamil Nadu 643223, India

\section{Dr. Martin Fisher}

Senior Associate Professor, Battcock Centre for Experimental Astrophysics, Cavendish

Laboratory, JJ Thomson Avenue, Cambridge CB3 OHE, UK

\section{Dr. John Fellowes}

Honorary Assistant Professor, The Kadoorie Institute, 8/F, T.T. Tsui Building, The University of Hong Kong, Pokfulam Road, Hong Kong

\section{Prof. Dr. Mirco Solé}

Universidade Estadual de Santa Cruz, Departamento de Ciências Biológicas, Vice-coordenado do Programa de Pós-Graduação em Zoologia, Rodovia Ilhéus/Itabuna, Km 16 (45662-000)

Salobrinho, Ilhéus - Bahia - Brasil

\section{Dr. Rajeev Raghavan}

Professor of Taxonomy, Kerala University of Fisheries \& Ocean Studies, Kochi, Kerala, India

\section{English Editors}

Mrs. Mira Bhojwani, Pune, India

Dr. Fred Pluthero, Toronto, Canad

Mr. P. Ilangovan, Chennai, India

Web Maintenance

Mrs. Latha G. Ravikumar, ZOO/WILD, Coimbatore, India

\section{Typesetting}

Mr. Arul Jagadish, ZOO, Coimbatore, India

Mrs. Radhika, ZOO, Coimbatore, India

Mrs. Geetha, ZOO, Coimbatore India

\section{Fundraising/Communications}

Mrs. Payal B. Molur, Coimbatore, India

Subject Editors 2018-2020

Fungi

Dr. B. Shivaraju, Bengaluru, Karnataka, India

Dr. R.K. Verma, Tropical Forest Research Institute, Jabalpur, India

Dr. Vatsavaya S. Raju, Kakatiay University, Warangal, Andhra Pradesh, India

Dr. M. Krishnappa, Jnana Sahyadri, Kuvempu University, Shimoga, Karnataka, India

Dr. K.R. Sridhar, Mangalore University, Mangalagangotri, Mangalore, Karnataka, India

Dr. Gunjan Biswas, Vidyasagar University, Midnapore, West Bengal, India

Plants

Dr. G.P. Sinha, Botanical Survey of India, Allahabad, India

Dr. N.P. Balakrishnan, Ret. Joint Director, BSI, Coimbatore, India

Dr. Shonil Bhagwat, Open University and University of Oxford, UK

Prof. D.J. Bhat, Retd. Professor, Goa University, Goa, India

Dr. Ferdinando Boero, Università del Salento, Lecce, Italy

Dr. Dale R. Calder, Royal Ontaro Museum, Toronto, Ontario, Canada

Dr. Cleofas Cervancia, Univ. of Philippines Los Baños College Laguna, Philippines

Dr. F.B. Vincent Florens, University of Mauritius, Mauritius

Dr. Merlin Franco, Curtin University, Malaysia

Dr. V. Irudayaraj, St. Xavier's College, Palayamkottai, Tamil Nadu, India

Dr. B.S. Kholia, Botanical Survey of India, Gangtok, Sikkim, India

Dr. Pankaj Kumar, Kadoorie Farm and Botanic Garden Corporation, Hong Kong S.A.R., China

Dr. V. Sampath Kumar, Botanical Survey of India, Howrah, West Bengal, India

Dr. A.J. Solomon Raju, Andhra University, Visakhapatnam, India

Dr. Vijayasankar Raman, University of Mississippi, USA

Dr. B. Ravi Prasad Rao, Sri Krishnadevaraya University, Anantpur, India

Dr. K. Ravikumar, FRLHT, Bengaluru, Karnataka, India

Dr. Aparna Watve, Pune, Maharashtra, India

Dr. Qiang Liu, Xishuangbanna Tropical Botanical Garden, Yunnan, China

Dr. Noor Azhar Mohamed Shazili, Universiti Malaysia Terengganu, Kuala Terengganu, Malaysia Dr. M.K. Vasudeva Rao, Shiv Ranjani Housing Society, Pune, Maharashtra, India

Prof. A.J. Solomon Raju, Andhra University, Visakhapatnam, India

Dr. Mandar Datar, Agharkar Research Institute, Pune, Maharashtra, India

Dr. M.K. Janarthanam, Goa University, Goa, India

Dr. K. Karthigeyan, Botanical Survey of India, India

Dr. Errol Vela, University of Montpellier, Montpellier, France

Dr. P. Lakshminarasimhan, Botanical Survey of India, Howrah, India

Dr. Larry R. Noblick, Montgomery Botanical Center, Miami, USA

Dr. K. Haridasan, Pallavur, Palakkad District, Kerala, India

Dr. Analinda Manila-Fajard, University of the Philippines Los Banos, Laguna, Philippines

Dr. P.A. Sinu, Central University of Kerala, Kasaragod, Kerala, India

Dr. Afroz Alam, Banasthali Vidyapith (accredited A grade by NAAC), Rajasthan, India

Dr. K.P. Rajesh, Zamorin's Guruvayurappan College, GA College PO, Kozhikode, Kerala, India

Dr. David E. Boufford, Harvard University Herbaria, Cambridge, MA 02138-2020, USA

Dr. Ritesh Kumar Choudhary, Agharkar Research Institute, Pune, Maharashtra, India

Dr. Navendu Page, Wildlife Institute of India, Chandrabani, Dehradun, Uttarakhand, India

Invertebrates

Dr. R.K. Avasthi, Rohtak University, Haryana, India

Dr. D.B. Bastawade, Maharashtra, India

Dr. Partha Pratim Bhattacharjee, Tripura University, Suryamaninagar, India

Dr. Kailash Chandra, Zoological Survey of India, Jabalpur, Madhya Pradesh, India

Dr. Ansie Dippenaar-Schoeman, University of Pretoria, Queenswood, South Africa

Dr. Rory Dow, National Museum of natural History Naturalis, The Netherlands

Dr. Brian Fisher, California Academy of Sciences, USA

Dr. Richard Gallon, llandudno, North Wales, LL30 1UP

Dr. Hemant V. Ghate, Modern College, Pune, India

Dr. M. Monwar Hossain, Jahangirnagar University, Dhaka, Bangladesh

Mr. Jatishwor Singh Irungbam, Biology Centre CAS, Branišovská, Czech Republic.

Dr. lan J. Kitching, Natural History Museum, Cromwell Road, UK

Dr. George Mathew, Kerala Forest Research Institute, Peechi, India

Dr. John Noyes, Natural History Museum, London, UK

For Focus, Scope, Aims, and Policies, visit https://threatenedtaxa.org/index.php/JoTT/aims_scope
For Article Submission Guidelines, visit https://threatenedtaxa.org/index.php/JoTT/about/submissions
For Policies against Scientific Misconduct, visit https://threatenedtaxa.org/index.php/JoTT/policies_various

continued on the back inside cover 


\title{
Habitat use and conservation threats to Wild Water Buffalo Bubalus arnee (Mammalia: Artiodactyla: Bovidae) in Koshi Tappu Wildlife Reserve, Nepal
}

\author{
Reeta Khulal ${ }^{1}$ (D), Bijaya Neupane ${ }^{2}$ (D), Bijaya Dhami ${ }^{3}$ (D), Siddhartha Regmi ${ }^{4}$ (D), \\ Ganesh Prasad Tiwari ${ }^{5}$ (D) \& Manita Parajuli 6 (D)
}

\author{
${ }^{1}$ Tribhuvan University, Institute of Forestry, Office of Dean, Kirtipur, Kathmandu, 44600, Nepal. \\ ${ }^{2,3,6}$ Tribhuvan University, Institute of Forestry, Pokhara Campus, Pokhara, 33700, Nepal. \\ ${ }^{4}$ Tribhuvan University, Institute of Forestry, Hetauda Campus, Hetauda, 44107, Nepal. \\ ${ }^{5}$ Agriculture and Forestry University, Faculty of Forestry, Hetauda, 44107, Nepal. \\ ${ }^{1}$ reetkc9336@gmail.com, ${ }^{2}$ bijneu@gmail.com (corresponding author), ${ }^{3}$ bijaysinghdhami@gmail.com, ${ }^{4}$ iregmisid@gmail.com, \\ ${ }^{5}$ tiwari.ganesh24@gmail.com, ${ }^{6}$ manitaparajuli11@gmail.com
}

\begin{abstract}
Wild Water Buffalo (WWB) Bubalus arnee is an endangered species and a protected animal in Nepal. The remaining WWB population is located in Koshi Tappu Wildlife Reserve (KTWR), and it appears to have low viability under prevailing conditions. We assessed the habitat use and conservation threats to wild water buffalo in KTWR. For habitat analysis the quadrant method was used. Eighty-four quadrants of $25 \mathrm{~m}^{2}$ for trees, 168 quadrants of $10 \mathrm{~m}^{2}$ for shrubs and 336 quadrants of $1 \mathrm{~m}^{2}$ for herbs were laid out in the study area. Ivlev's electivity index (IV) was calculated to assess the use of different habitat components. The important Value Index (IVI) was used for vegetation assessment. A relative threat ranking method was used to assess conservation threats for wild buffalo and their habitats. Wild buffalo mostly preferred habitats with distance to water resources less than $500 \mathrm{~m}$ (IV= 0.4 ), less than $25 \%$ crown coverage (IV= 0.39) and more than $75 \%$ ground coverage (IV=0.42). The trees species Phyllanthus emblica, Acacia catechu, shrub species Mimosa pudica and the herb species Brachiaria distachya, Vetiveria zizanioides, Imperata cylindrica, and Saccharum spontaneum were preferred by WWB in the study area. Among the different plant categories, we found that Acacia catechu was the most preferred tree species (IVI= 156.95), Mimosa pudica the most preferred shrub species (IVI= 58.68), and Imperata cylindrica the most preferred herb species (IVI= 64.73). Major conservation threats perceived by local stakeholders for wild buffaloes were overgrazing by cattle and genetic swamping through crossbreeding with domestic buffalo. Therefore, conservation of grass species through control of grazing, and prevention of cross breeding are measures supported by this study. Additionally, site-specific conservation strategies should be adopted, based on identified threats in the study area.
\end{abstract}

Keywords: Crossbreeding, endangered, genetic swamping, important value index, Ivlev's electivity index, quadrats.

Citation: Khulal, R., B. Neupane, B. Dhami, S. Regmi, G.P. Tiwari \& M. Parajuli (2021). Habitat use and conservation threats to Wild Water Buffalo Bubalus arnee (Mammalia: Artiodactyla: Bovidae) in Koshi Tappu Wildlife Reserve, Nepal. Journal of Threatened Taxa 13(12): 19714-19724. https://doi.org/10.11609/ jott.7584.13.12.19714-19724

Copyright: (c) Khulal et al. 2021. Creative Commons Attribution 4.0 International License. JoTT allows unrestricted use, reproduction, and distribution of this article in any medium by providing adequate credit to the author(s) and the source of publication.

Funding: This was self-funded research of M.Sc student Reeta Khulal, although instrument was provided by her Institution

"Tribhuvan University" during the field research.

Competing interests: The authors declare no competing interests.

Author details: REETA KHULAL is a MSc graduate in wildlife, protected area management, and biodiversity conservation. BIJAYA NEUPANE is an assistant professor in wildlife and protected area management working with the Department of Park Recreation and Wildlife Management at his institution since December 2016. He possesses more than 5 years of research and teaching experiences in ecology and wildlife conservation in Nepal as well as some field and lab experiences in Norway and Sweden. BIJAYA DHAMI is a BSC Forestry final year student and is actively involved in several conservation activities and is a president of his NGO, one of the green organization of Pokhara. SIDDHARTHA REGMI is a BSC Forestry graduate and now he is working as a research technician in conservation NGO, Care for Nature, Nepal and is directly involved in numerous wildlife related projects. GANESH PRASAD TIWARI is a MSc Forestry student. MANITA PARAJULI is a BSc final year student.

Author contributions: Conceptualization and research design - RK and BN; Data collection - RK and GPT; Data analysis and interpretation - RK, BN, BD and SR; Manuscript preparation - RK, BN, BD and SR; Editorial input - BN, BD, SR and MP; Critical review and revision at different stages - all authors contributed equally; Finalizing the manuscript - RK, BN and MP; correspondence with the journal - BN.

Acknowledgements: We are very grateful to: the Department of National Parks and Wildlife Conservation (DNPWC) and Koshi Tappu Wildlife Reserve (KTWR) for permitting us to conduct this study; Tribhuvan University, Institute of Forestry for the instrument support during the fieldwork; Prof. Achyut Raj Gyawali and Assist. Prof. Mr. Deepak Gautam for their continuous encouragement and support throughout this study; Dr. Menuka Maharjan, Mr. Subash Budathoki, and Ms. Sangeeta Timilsina for their valuable supports and contributions during the field survey; the local people and representatives of local organizations who assisted us during our fieldwork; and all the anonymous reviewers and editors for their precious time, suggestions, and comments to improve this manuscript. 


\section{INTRODUCTION}

Nepal has two zoogeographic regions: Palearctic and Oriental, and is known for faunal diversity including 212 species of mammals (Baral \& Shah 2008; Jnawali et al. 2011; Amin et al. 2018), including 49 threatened species. The Wild Water Buffalo Bubalus arnee (WWB), also called Wild Asian Buffalo (Image 1) is a large bovine native to southern and southeastern Asia (Dahmer 1978), which primarily occurs in tropical, subtropical forest, and swampy grasslands (Thapa et al. 2020). It is legally protected in India, Nepal, Cambodia, Myanmar, Thailand, and Bhutan (Groves 1981). This species is categorized as 'Endangered' mammal species on the International Union for Conservation of Nature (IUCN) Red List of Threatened Species (Kaul et al. 2019) and in Appendix III of the Convention on International Trade in Endangered Species of wild fauna and flora (CITES) (CITES 2017). It is one of the protected mammals included in Nepal's National Parks and Wildlife Conservation Act, 1973 (GoN 1973).

WWB is a large powerful animal that weighs between 800-1,200 kg, with horn span of around $2 \mathrm{~m}$ (Aryal et al. 2011). Home ranges are $1.7-10 \mathrm{~km}^{2}$ (Nowak 1999). Generally, males are able to breed after 18 months while females are able after 3 years. The pregnant female undergoes a gestation period of 12 months and gives birth to a single calf at a time, with a minimum birth interval of about 2 years (Shrestha 1997). In the wild, WWB can live up to 25 years, and in captivity up to 29 years (Roth 2004). They are social animals and typically form herds of 10-20 individuals, with herds of up to 100 having been witnessed (Heinen 1993). Being intensely reliant on water and investing significant time wallowing in puddles or rivers, they are frequently sighted in swamps and marshes, grasslands, and riverine forests (Roth 2004). WWB usually prefer marshy floodplains with towering elephant grass (e.g., Saccharum and Phragmites) and scrubby wooded forests of Bombax, Dalbergia, and Acacia (Sah 1997). Additionally, open short grasslands, forests and agriculture fields provide good shelter (Adhikari 1999).

In Nepal, Koshi Tappu Wildlife Reserve (KTWR), established in 1976, shelters the last enduring population of WWB, consisting of 498 individuals (DNPWC 2021). With the aim to establish a second sub-population of WWB, 15 individuals were translocated and kept in an enclosure in Chitwan National Park in January 2017, but their viability is not yet ensured (Shah et al. 2017). Thus conserving WWB in KTWR is a serious issue that is getting more critical every year. The species and their habitat have been mainly threatened by human interference, including illegal hunting, habitat fragmentation, and degradation (Heinen \& Kandel 2006; Kafle et al. 2020). Besides, there is also the severe problem of crossbreeding with domestic buffalo (Khatri et al. 2012), consequently losing the genetic diversity of the species (Kaul et al. 2019). There is only about $0.8 \mathrm{~km}^{2}$ area per individual WWB in the reserve, which is inadequate to sustain a thriving buffalo population (Aryal et al. 2011).

Apart from habitat-use information, it is essential for conservationists to find out the threat status of an ecological community (Nicholson et al. 2009; Joshi et al. 2020) to plan and implement conservation activities effectively. The threat ranking method used by WWF in the Standards of Project and Program Management shows the degree to which each direct threat affects the biodiversity target at a given site (WWF 2007). In this study, a similar technique was employed, which consisted of recognizing a set of standards and applying them to direct risks in order to develop a conservation action plan by focusing on the areas where they are most needed. To our knowledge, very limited studies have been conducted particularly on the habitat use and threats of WWB in the study area, so this study attempts to fulfill such information gap that can help the conservationists, planners, and reserve managers to implement the required conservation measures for such threatened and isolated species.

\section{MATERIALS AND METHODS}

\section{Study area}

The KTWR extends from 86.916-87.0830 $\mathrm{E}$ to 26.566-26.7510 N and is located in Eastern Nepal's Saptari, Sunsari, and Udaypur districts, on the alluvial flood plains of the Sapta Koshi River (Figure 1). It covers a total core area of $175 \mathrm{~km}^{2}$ with an additional buffer zone of about $173 \mathrm{~km}^{2}$ surrounding the reserve, declared in 2004. Recognizing the reserve's significance, it was assigned as a wetland of global significance and included in the Ramsar list on 17 December 1987 (IUCN 1990). The reserve is mostly comprised of riverine grasslands (56\%), sand \& gravel deposits (22\%), agricultural field (5\%), forest land (1\%), river \& stream $(10 \%)$, marshes \& swamps (6\%), and lake \& pond (0.01\%) (Chettri et al. 2013). It is listed as an important bird area where 490 species of birds have been recorded (Shrestha \& Pantha 2018). Natural predators of WWB such as Leopard Panthera pardus, Dhole Cuon alpinus, Tiger Panthera tigris, were wiped out from KTWR for at the last 40 years 


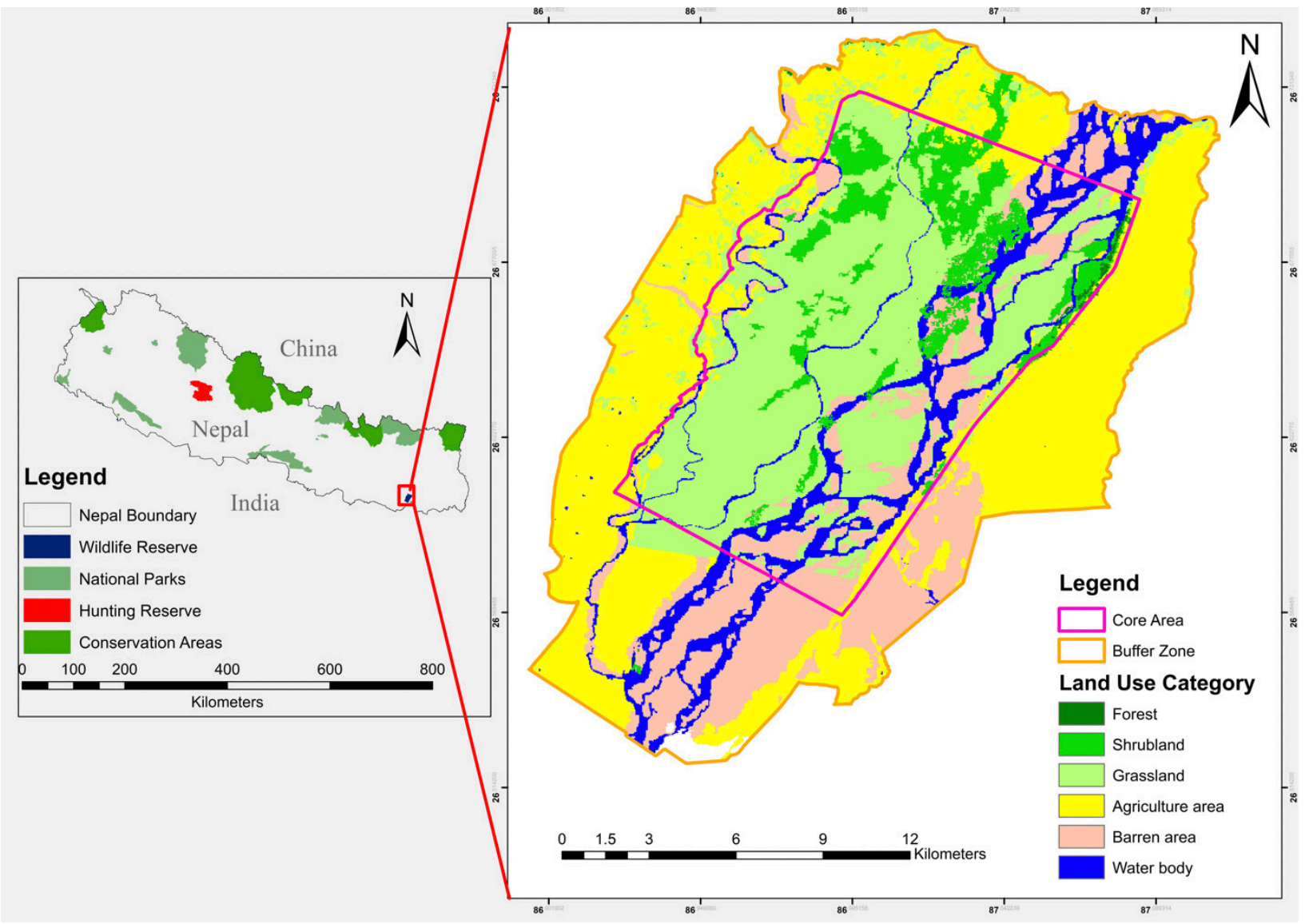

Figure 1. Map of the study area (Koshi Tappu Wildlife Reserve, Nepal).

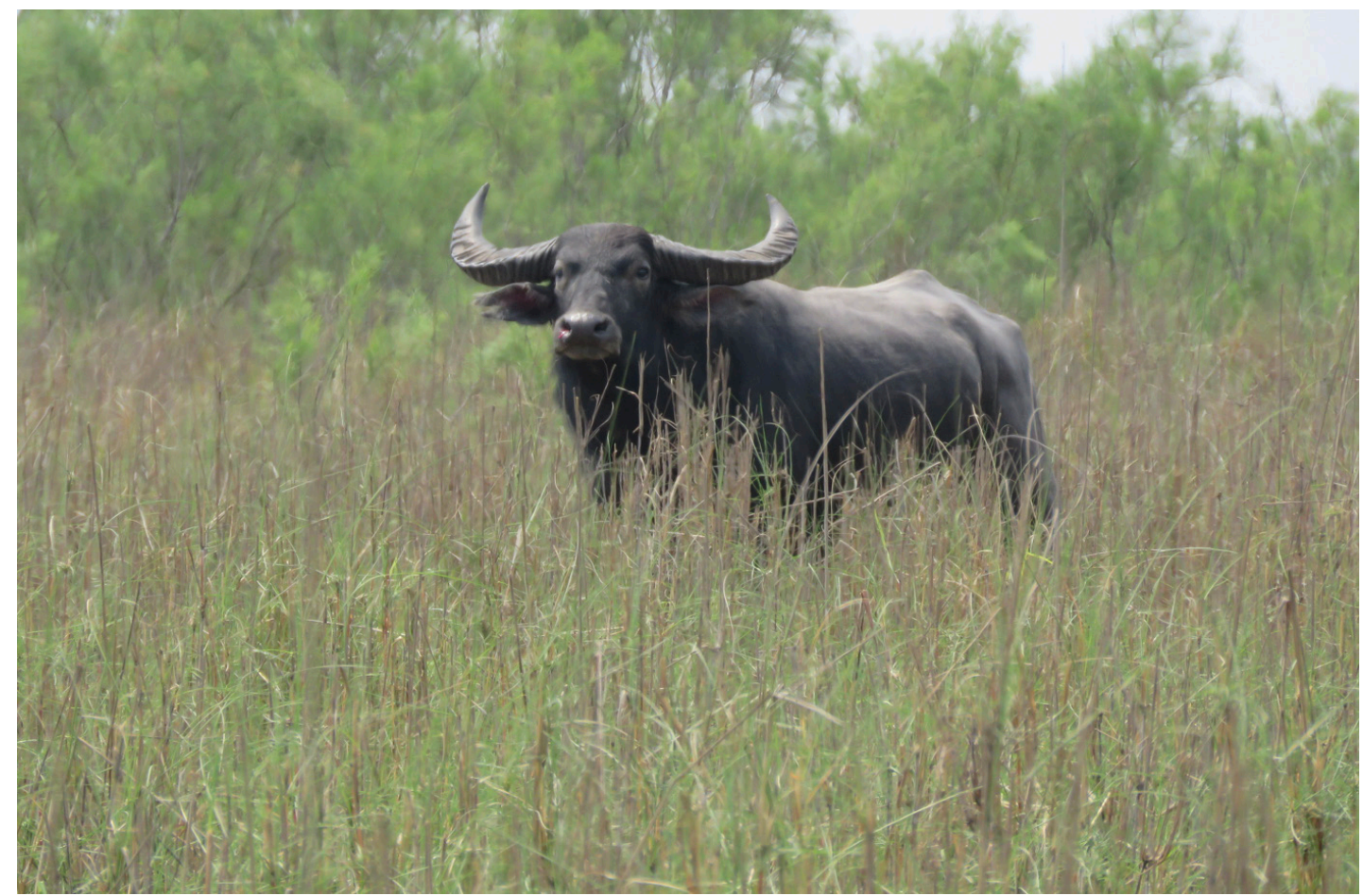

Image 1. Wild Water Buffalo Bubalus arnee sighted in KTWR. @ Reeta Khulal. 


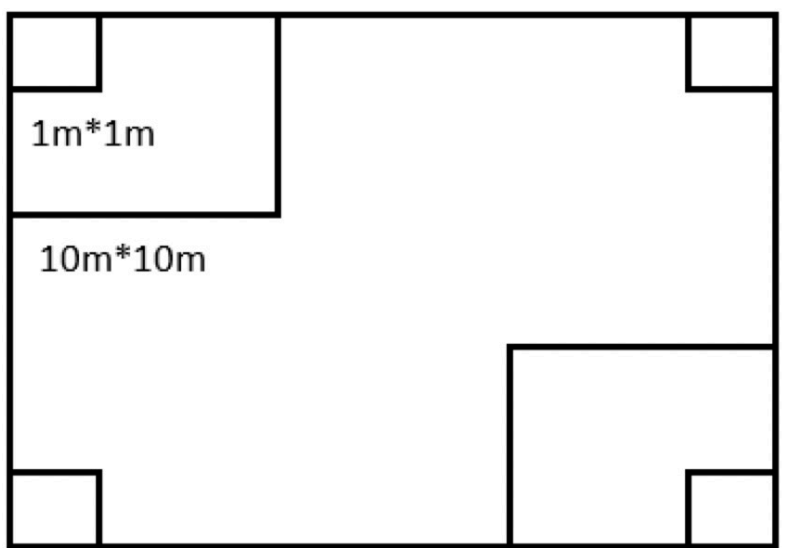

$25 m * 25 m$

Figure 2. Layout of quadrant in the study area.

(Heinen \& Paudel 2015). The climate of the reserve is the tropical monsoonal type and the monsoon season, which runs from mid-June to late September, accounts for 80-85 percentage of total rainfall. The average monthly temperature ranges between $15.7^{\circ} \mathrm{C}$ and 29.2 ${ }^{\circ} \mathrm{C}$ and the average annual rainfall range from 1,300 $\mathrm{mm}$ to $2,050 \mathrm{~mm}$ with higher humidity that remains throughout the year.

\section{Data collection}

We conducted the field study between December 2019 and January 2020. In the initial phase, all the potential sites of WWB, in consultation with the experienced park staff and warden, were surveyed for evidence such as droppings, exudation of sap, crushed tissues, fresh clipping, and direct sighting during the active periods of dawn and dusk (Heinen \& Singh 2001). Then, a random sampling method was adopted to identify different attributes of habitat associated with WWB. Both Habitat Use plots " $U$ " and Availability plots " $A$ " were established on those sites. In each location where the indirect evidence (droppings, hair, pugmarks, bedding sites, and horns) of the WWB were observed; the habitat use plot was established within a distance of $50 \mathrm{~m}$ (Neupane et al. 2021). Different habitat attributes from each plot such as ground cover, crown cover, and distance to water source were noted. Further, Availability plots were established within $100 \mathrm{~m}$ distance from the Use plots in random direction (Neupane et al. 2021). Similar habitat attributes were noted in each availability plot as noted in use plots. If any signs of the WWB were observed in availability plots, the availability plots were renamed as use plots. Vegetation analysis was conducted on both the availability and use plots.
Eighty-four quadrants each of size $25 \times 25$ m for trees; 168 nested quadrants of $10 \times 10 \mathrm{~m}$ for shrubs and 336 nested quadrants of $1 \times 1 \mathrm{~m}$ for herbs were laid out randomly on those selected sites (Figure 2). Within each quadrant, all the trees were counted and their diameter at breast height $(\mathrm{DBH})$, and heights were assessed using diameter tape and clinometers respectively. Similarly, the species composition and percentage cover of shrubs and herbs and their respective frequencies were noted.

Threat assessment was done by direct field observation and through interviews with the local people, local experts, and reserve authorities in the study area. These interviewees were conducted with different local stakeholders who have been residing there for more than 20 years and are familiar with the WWB and their habitats, following a similar method used in the previous studies (Chhetri et al. 2020; Neupane et al. 2020). Literature reviews were also conducted to gather information on various facets of each threat. Interviews were taken with conservation officers, political pioneers, and heads of the metropolitan wards to investigate their insight and perspectives on the existing threats to WWB and their habitats. We assigned the scope, severity, urgency, and irreversibility ratings of each threat component, and based on the information gained from these methods, we ranked the threats using the relative threat ranking method.

\section{Data analysis}

The habitat utilization of WWB was analyzed using Ivlev's electivity index (IV), whose value ranges in between +1 to -1 . The positive value of IV indicates habitat utilization and negative value indicates habitat avoidance and finally, zero value indicate random utilization of the habitat (Ivlev 1961). The (IV) value was calculated using following formula.

$\mathrm{IV}=(\mathrm{U} \%-\mathrm{A} \%) /(\mathrm{U} \%+\mathrm{A} \%)$ (Ivlev 1961; Yonzon \& Hunter 1989; Neupane et al. 2021).

Percentage of crown cover as well as ground cover was divided into four categories that include 0-25\%, 26-50\%, 51-75\%, and 76-100\%. Vegetation analysis and calculations was done according to the methods suggested by Zobel et al. (1987) with the formula mentioned below.

\begin{tabular}{|c|c|}
\hline & $\begin{array}{c}\text { Number of individual of A species in al } \\
\text { quadrates } \times 100 \%\end{array}$ \\
\hline ensity of species $A$ & $\begin{array}{l}\text { Total number of quadrates studied } \\
\text { x Size of quadrate taken }\end{array}$ \\
\hline
\end{tabular}

Relative density of species $A=\frac{\text { Density of species A occurred } \times 100 \%}{\text { Sum of all density }}$ 
Table 1. Interpretations of criteria and associated rankings used to prioritize each threat (adapted from TNC 2007; WWF 2007; NHWAP 2015).

\begin{tabular}{|c|c|}
\hline Criteria and rankings & Definition \\
\hline Scope & The geographical extent of impact on the biological target that can be fairly foreseen within 10 years under existing conditions \\
\hline Very high & The threat is expected to be pervasive in its scope, influencing the target over all or most (71-100\%) of its occurrence/population. \\
\hline High & The threat is expected to be widespread in its scope, influencing the target over (31-70\%) of its occurrence/population \\
\hline Medium & The threat is expected to be restricted in its scope, influencing the target over (11-30\%) of its occurrence/population \\
\hline Low & The threat is expected to be very narrow in its scope, influencing the target over a less part (1-10\%) of its occurrence/population \\
\hline Severity & The degree of damage to biological target that may be realistically predicted within 50 years under existing conditions. \\
\hline Very high & $\begin{array}{l}\text { The threat is expected to eliminate or degrade the target or minimize its population by } 71-100 \% \text { within } 10 \text { years or } 3 \\
\text { generations, within the scope }\end{array}$ \\
\hline High & $\begin{array}{l}\text { The threat is expected to seriously degrade the target or minimize its population by } 31-70 \% \text { within } 10 \text { years or } 3 \text { generations, within } \\
\text { the scope }\end{array}$ \\
\hline Medium & $\begin{array}{l}\text { The threat is expected to moderately degrade the target or minimize its population by } 11-30 \% \text { within } 10 \text { years or } 3 \text { generations, within } \\
\text { the scope }\end{array}$ \\
\hline Low & $\begin{array}{l}\text { The threat is expected to slightly degrade the target or minimize its population by } 1-10 \% \text { within } 10 \text { years or } 3 \text { generations, within the } \\
\text { scope }\end{array}$ \\
\hline Urgency & This attribute is used to measure the certainty and time frame over which the threat's effects will be seen. \\
\hline Very high & The impacts of the threat are noticeable already and there is an urgency to take action to cope with the issue within a year. \\
\hline High & The impacts of the threat are likely to emerge and the issue are predicted during the upcoming 1-10 years. \\
\hline Medium & The impacts of the threat are likely to emerge and the issue are predicted within the upcoming $10-25$ years. \\
\hline Low & The impacts of the threat are unlikely to occur and the issue are predicted in about 25 years from now \\
\hline Irreversibility & The extent to which the impacts of a stressor can be reversed \\
\hline Very high & The threat's impact cannot be reverted and it is doubtful that the target can be recovered, and/or it would take 100 years to attain this \\
\hline High & $\begin{array}{l}\text { The threat's impact can technically be reverted and the target is likely to be recovered, but it is not feasible practically and/or it } \\
\text { may take long period i.e., } 21-100 \text { years to achieve this }\end{array}$ \\
\hline Medium & $\begin{array}{l}\text { The threat's impact can be reverted and the target is likely to be recovered with a sensible commitment of resources and/or } \\
\text { within 6-20 years }\end{array}$ \\
\hline Low & The threat's impact is quickly reversible and the target may be easily recovered at a reasonable cost and/or within $0-5$ years \\
\hline
\end{tabular}

No of quadrates in which species $A$ occurred x $100 \%$

Frequency of species $A=-$ Total number of quadrates studied

Frequency of species A occurred x $100 \%$ Relative frequency of species $A=$ Sum of total frequences

Basal area $=\frac{\pi \mathrm{d} 2}{4}$

Relative coverage $(\mathrm{RC})=\frac{\text { Coverage of a species } \times 100 \%}{\text { Total coverage of all species }}$

Basal area of species $\times 100 \%$

Relative basal area of species $A(R B A)=\frac{}{\text { Total basal area of all species }}$

In the community structure, importance value index (IVI) provides the general significance of every species and calculated as mentioned in equations (I) and (II).

$\mathrm{IVI}=\mathrm{RF}+\mathrm{RD}+\mathrm{RC}$ (for herbs and shrubs)

$\mathrm{IVI}=\mathrm{RF}+\mathrm{RD}+\mathrm{RBA}$ (for trees)

\section{Threat assessment}

A relative threat ranking method was followed in order to assess the conservation threats (TNC 2007; WWF 2007) and four scales of classification - scope, severity, urgency, and irreversibility (permanence) (Table 1) (NHWAP 2015) were used to identify and prioritize the major existing issues based on the collected data. Those four threat criteria were assigned to each of the identified issues and ranked with the highest rank equal to the number of total threats.

From these different fields, 10 types of major threats were identified and ranked as threats with the value of rank ranging from 1 to 10 , where the value 10 implies very high with serious effect, and value 1 implies very low with least effect, respectively. These values are categorized under a 4-point scale for analysis and categorized as Very High (VH), High (H), Medium (M), and Low (L). 
RESULTS

\section{HABITAT UTILIZATION}

Distance from water sources: WWB mostly utilized the distance less than $500 \mathrm{~m}(\mathrm{IV}=0.40)$, and randomly used distance more than $2000 \mathrm{~m}(\mathrm{IV}=0)$ from the water source. It is observed that as distance from water source increases, WWB avoided the use of the area (Figure 3).

Crown cover: WWB highly preferred the area with crown cover of $0-25 \%$ (IV $=0.39$ ) followed by $26-50 \%$ (IV= 0.13) and avoided 51-75\% (IV= -0.1$)$, and closed crown cover of $76-100 \%$ (IV= -0.25$)$ (Figure 4).

Ground cover: WWB highly utilized the area with 76$100 \%$ (IV= 0.42) ground cover followed by $0-25 \%$ (IV= $0.36)$, and $51-75 \%(I V=0.17)$, and randomly used the area with $25-50 \%$ ground cover (IV= 0) (Figure 5).

\section{Vegetation Analysis}

In total, we recorded nine major species of trees, nine shrub species, and 50 species of herbs in our study area. Out of nine major tree species, Acacia catechu possessed the highest IVI. Besides, six of them were preferred by
WWB whereas two of them were randomly used and one species was completely avoided. Among the nine major species of shrub, Mimosa pudica possessed the highest IVI among them, which was also the only preferred shrub species of WWB. Similarly, Ziziphus mauritiana and Cascabela thevetia were randomly used while other shrub species were avoided by WWB. Six of the 50 herb species commonly documented in the research region were preferred by WWB where Imperata cylindrica shared the highest IVI followed by Saccharum spontaneum, Phragmites karka and Cynodon dactylon as shown in Table 2.

\section{Threats assessment}

Among the 10 identified threats to WWB, overgrazing by domestic cattle and crossbreeding between domestic and WWB were ranked as the most severe threats in the study area. Similarly, invasion by weeds, disease and parasites, flooding and intensive utilization of forest resources were ranked as the high threats. Other threats with their ranked results are mentioned in Table 3.

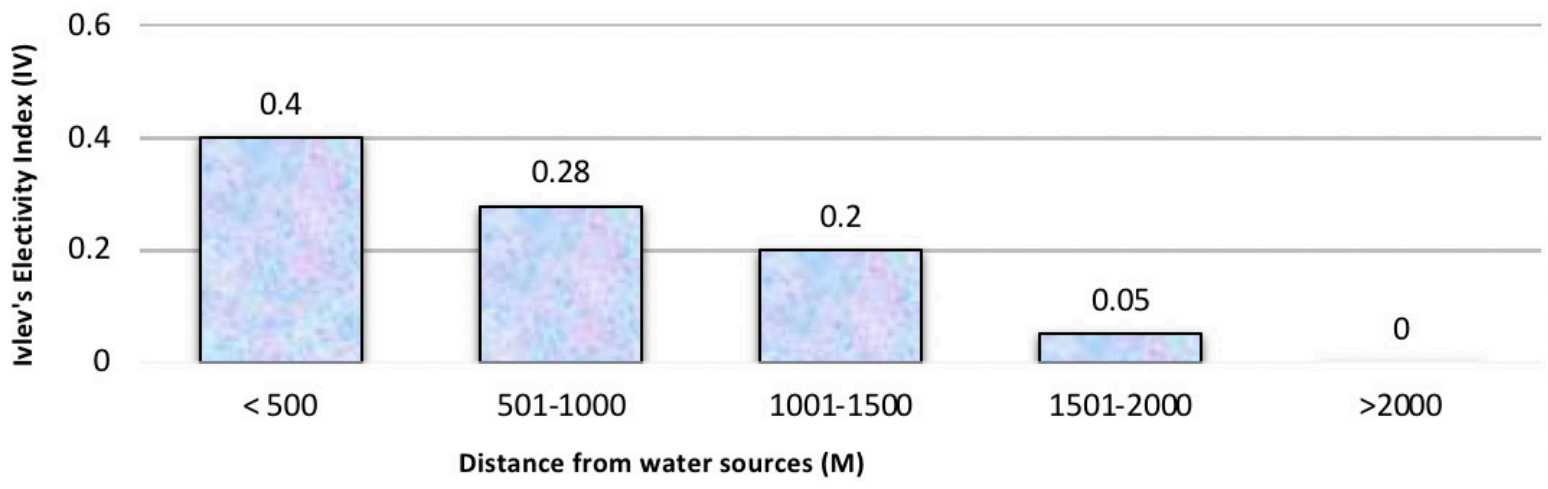

Figure 3. IV values with respect to distance from water sources.

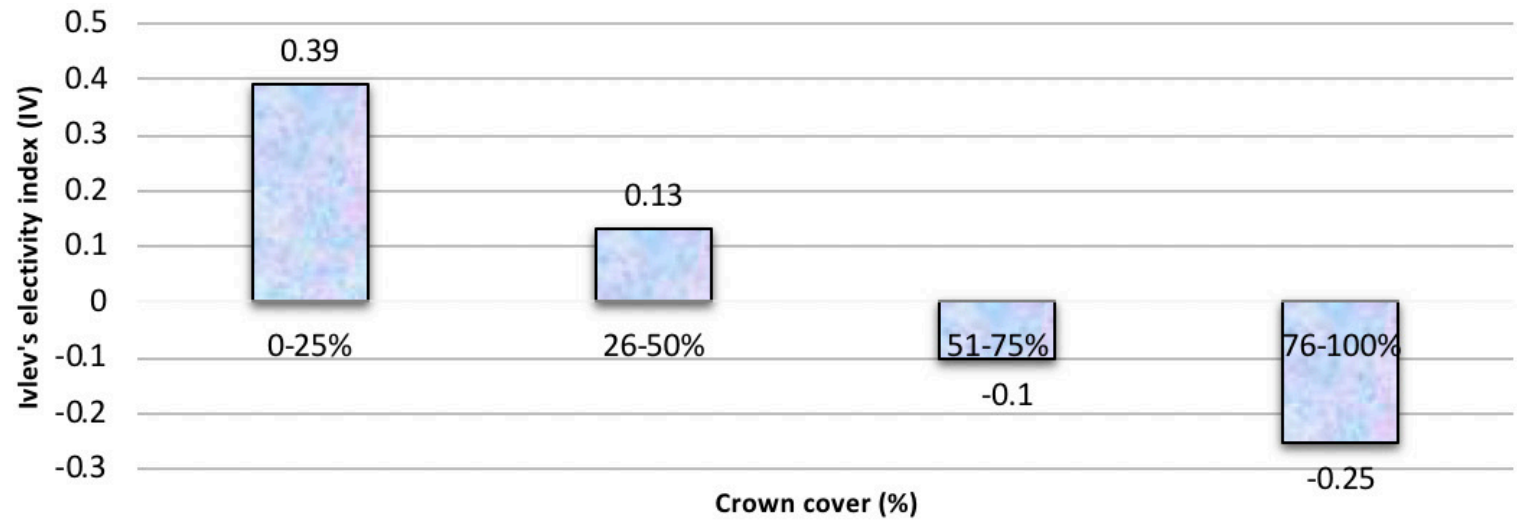

Figure 4. IV values with respect to percentage of crown cover 
Table 2. Most abundant tree, shrub, and herb species with IV and IVI values.

\begin{tabular}{|c|c|c|c|c|c|c|c|}
\hline & Species & Local Name & Family & Life form & IV & IVI & Preference \\
\hline 1 & Acacia catechu & Khair & Fabaceae & Tree & 0.34 & 94.85 & Preferred \\
\hline 2 & Dalbergia sissoo & Sissoo & Fabaceae & Tree & 0 & 36.02 & Random use \\
\hline 3 & Trewia nudiflora & Gutel & Euphorbiaceae & Tree & -0.25 & 26.32 & Avoided \\
\hline 4 & Bombax ceiba & Simal & Malvaceae & Tree & 0.18 & 21.97 & Preferred \\
\hline 5 & Streblus asper & Bedula & Moraceae & Tree & 0.25 & 9.91 & Preferred \\
\hline 6 & Phyllanthus emblica & Amala & Phyllanthaceae & Tree & 0.42 & 8.81 & Preferred \\
\hline 7 & Albizia chinensis & Kalo siris & Fabaceae & Tree & 0.17 & 5.35 & Preferred \\
\hline 8 & Mangifera indica & Aanp & Anacardiaceae & Tree & 0 & 2.89 & Random use \\
\hline 9 & Syzygium cumini & Jamun & Myrtaceae & Tree & 0.29 & 2.88 & Preferred \\
\hline 10 & Others & - & - & Tree & & 91 & - \\
\hline 11 & Mimosa pudica & Shy plant & Fabaceae & Shrub & 0.43 & 58.68 & Preferred \\
\hline 12 & Chromoleana odorata & Ban Masha & Asteraceae & Shrub & -0.95 & 42.25 & Avoided \\
\hline 13 & Lantana camara & Banmara & Verbenaceae & Shrub & -1.0 & 24.36 & Avoided \\
\hline 14 & Calotropis procera & Aank & Apocynaceae & Shrub & -1.0 & 19.35 & Avoided \\
\hline 15 & Ziziphus mauritiana & Bayer & Rhamnaceae & Shrub & 0 & 18.18 & Random used \\
\hline 16 & Xanthium strumarium & - & Asteraceae & Shrub & -0.17 & 15.64 & Avoided \\
\hline 17 & Jatropha curcas & Sajiwan & Euphorbiaceae & Shrub & -0.31 & 13.58 & Avoided \\
\hline 18 & Datura metel & Dhaturo & Solanaceae & Shrub & -0.42 & 12.89 & Avoided \\
\hline 19 & Cascabela thevetia & Yellow oleander & Apocynaceae & Shrub & 0 & 8.1895 & Random used \\
\hline 20 & Others & - & - & Shrub & & 86.873 & Preferred \\
\hline 21 & Imperata cylindrica & Siru & Poaceae & Herb & 0.56 & 64.73 & Preferred \\
\hline 22 & Saccharum spontaneum & Kash & Poaceae & Herb & 0.49 & 61.47 & Preferred \\
\hline 23 & Phragmites karka & Narkat & Poaceae & Herb & 0.31 & 44.55 & Preferred \\
\hline 24 & Cynodon dactylon & Dubo & Poaceae & Herb & 0.65 & 34.46 & Preferred \\
\hline 25 & Brachiaria distachya & Bansho ghas & Poaceae & Herb & 0.90 & 21.97 & Preferred \\
\hline 26 & Vetiveria zizanioides & Kus & Poaceae & Herb & 0.82 & 16.31 & Preferred \\
\hline 27 & Others & - & - & Herb & & 56.50 & - \\
\hline
\end{tabular}

Table 3. Relative ranking of the most severe threats.

\begin{tabular}{|c|c|c|c|c|c|c|c|}
\hline & Threats & Scope & Severity & Urgency & Irreversibility & Total & $\begin{array}{c}\text { Threat } \\
\text { Classification }\end{array}$ \\
\hline 1 & Overgrazing & 10 & 9 & 10 & 8 & 37 & Very high \\
\hline 2 & $\begin{array}{l}\text { Crossbreeding between domestic and Wild } \\
\text { Water Buffalo }\end{array}$ & 9 & 8 & 9 & 9 & 35 & Very high \\
\hline 3 & Flooding & 8 & 7 & 7 & 8 & 30 & High \\
\hline 4 & Invasion by weeds & 7 & 8 & 7 & 6 & 28 & High \\
\hline 5 & Intensive utilization of the forest resources & 6 & 6 & 7 & 6 & 25 & High \\
\hline 6 & Disease and parasite & 5 & 5 & 4 & 7 & 21 & High \\
\hline 7 & Road traffic accident & 4 & 4 & 4 & 5 & 17 & Medium \\
\hline 8 & Hunting and poaching & 2 & 3 & 3 & 3 & 11 & Medium \\
\hline 9 & Poisoning & 2 & 2 & 2 & 1 & 7 & Low \\
\hline \multirow[t]{2}{*}{10} & Electrocution & 1 & 2 & 1 & 1 & 5 & Low \\
\hline & Total & 54 & 54 & 54 & 54 & 216 & \\
\hline
\end{tabular}




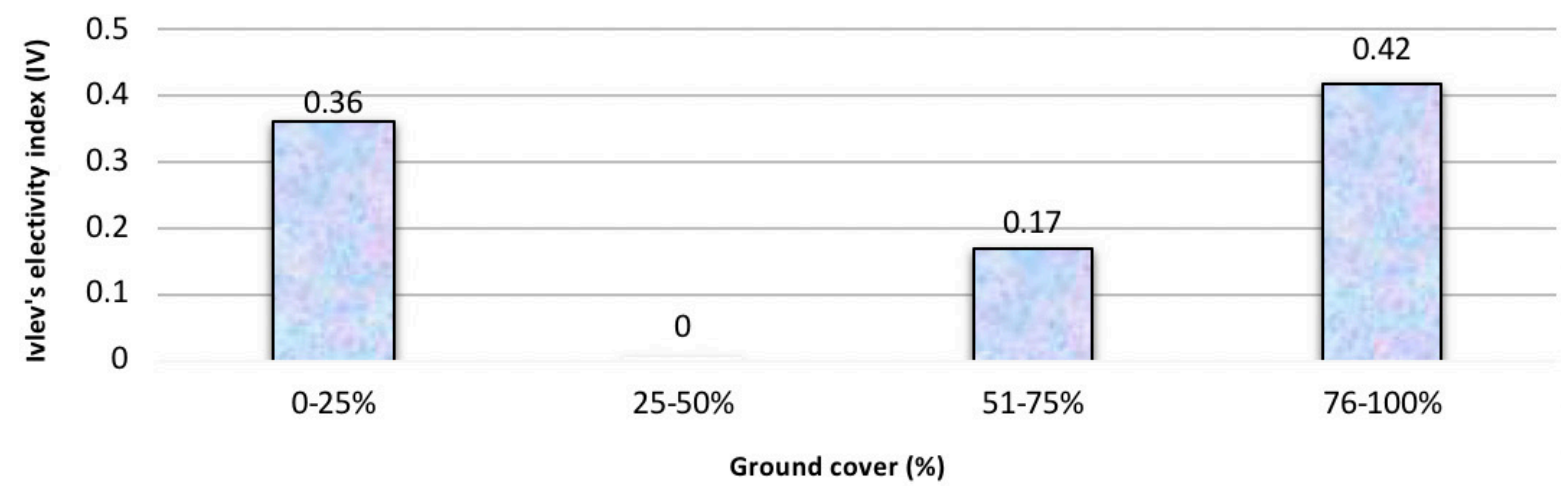

Figure 5. IV values with respect to percentage of ground cover.

\section{DISCUSSION}

Our study showed that WWB preferred the area within the distance of $500 \mathrm{~m}$ from the river and the habitat use got decreased with increasing distance from those sources. This might be because WWB require continuous supply of water for wallowing. Supporting this fact, Singh (2015) have reported that WWB home range size extends up to 3.9 miles $^{2}$ that mainly consist of water bodies, grazing area and resting sheds. Similarly, the study carried out by Dahmer (1978) indicated that the visibility of WWB is seen less frequent in the dense vegetation. Our study also showed that WWB mostly used the area with crown cover of only 0-25\% and avoided the area with crown cover more than $50 \%$. This might be because the dense crown cover does not permit the entry of light that is necessary for the growth of ground cover and necessitates greater alertness to the predators. Likewise, we observed that WWB mostly preferred the ground cover of $76-100 \%$. This preference is obvious because WWB is a chief grazer (Ram \& Sharma 2011) and selects area with dense ground cover to fulfill the dietary requirements.

With regard to types of vegetation, a study conducted in Thailand revealed that Saccharum arundinaceum and S. spontaneum were preferred by WWB (Bolton 1975). Likewise, a study carried out by Lama (2013) in KTWR showed that Imperata cylindrica, Cynodon dactylon, and Saccharum spontaneum were preferred by WWB, similar to the findings of our study. This might be because the KTWR is dominated by the above-mentioned species as shown by their IVI values. Parihar et al. (1986) showed that Dalbergia sissoo, Acacia catechu and Bombax ceiba were the preferred tree species in Kanha National Park and Lama (2013) mentioned that WWB preferred AcaciaDalbergia associated forest in KTWR. However, our study shows that Phyllanthus emblica and Acacia catechu were the most preferred tree species while Dalbergia sissoo was randomly used. Majority of the shrub species were avoided by WWB in our study. Siwakoti (2009) identified these species as invasive species in KTWR, which are regarded as problematic species by Aryal et al. (2011).

WWB face serious threats in KTWR (Heinen \& Kandel 2006). Our study demonstrated that open grazing and crossbreeding with domestic buffalo are the critical threats to WWB survival in KTWR. To settle the problem of over grazing, conservation managers had adopted a few strategies in the past like culling buffaloes of domestic origin with the permission from DNPWC in 2001, evacuation of domestic cattle from the park between 2004-2005 and 2010 through a sweeping method (DNPWC 2020). However, these strategies were ineffective. Livestock farming is a traditional mode of subsistence for many people in buffer zone. There are few public lands left outside for grazing, so there is no alternative to use of the reserve as a land for grazing and bringing their livestock into the reserve for sharing food with the wild animals. Hence, providing incentives to the local farmer to initiate stall-feeding might help to control over grazing inside the park.

The small size of the reserve and higher number of livestock inside it is leading to problems of both inbreeding of WWB and cross-breeding with domestic buffalo. Low genetic variation among WWB groups is linked to the practices of local farmers, who crossbreed domestic females with wild males (Heinen 2001). Flamand et al. (2003) conducted genetic analysis to validate that the reserve consists of pure wild stock, and found that three genetically identifiable populations of buffalo were present in the KTWR: wild, domestic and backcrossed. A study carried by Aryal et al. (2011) supports our findings in that they identified livestock grazing inside the KTWR as serious threat to WWB and their foraging plant species. Adhikari (2006) also 
reported overgrazing as major threat, as extensive grazing retards plant regeneration. Similarly, Khatri et al. (2012) and (KTWR 2018) reported crossbreeding as the major threat in KTWR similar to our study. Further, our study shows that existing threats like flooding, invasion by weeds, intensive forest resource extraction, disease and parasite are of high level, which is supported by several studies. Aryal et al. (2011) stated flooding as the significant threat in KTWR, which is similar to our finding. Flash floods during monsoons also have a high chance of impacting WWB, especially calves.

Similar to our findings, Khatri et al. (2012) reported invasive weeds as serious threat to native vegetation, including species preferred by WWB. Weeds like Lantana camera, Chromolaena odorta cover most of the study area and are invading forest areas and grasslands of the reserve, which is leading to loss of food and destruction of habitat. Similar to our study, Aryal et al. (2011) noted that over-harvesting and uncontrolled use of reserve resources are the major threats, where the local community enter the reserve in unauthorized manner and accumulate grass and other forest product (Heinen \& Kandel 2006). Food preferred by WWB, such as Imperata cylindrica, Saccharum spontaneum, Typha elephentina, and Cynodon dactylon, are used by local people for fodder, firewood and making mats, brooms and baskets. Similar to our study, transfer of disease and parasite from domestic cattle to WWB is also regarded among the major threats (Aryal et al. 2011; Heinen \& Paudel 2015) since there is close overlap of WWB and domestic livestock, the high density particularly of latter, and the small and localized nature of WWB population.

Several strategies have been developed to conserve the endangered population of the WWB of KTWR in joint efforts by the Government of Nepal with other stakeholders using the habitat. In order to minimize conflicts between local people and the reserve, an area of $173.5 \mathrm{~km}^{2}$ adjoining to KTWR was set up in 2004 as a buffer zone which is the innovational strategy for participatory conservation (Khatri et al. 2012). Further, the management plan of KTWR approved in 2010 is now revised as the management plan (2018-2022) with the vision to manage ecological integrity and to conserve biological diversity of the reserve (KTWR 2018). Likewise, with the assistance of Conservation and Sustainable Use of Wetlands in Nepal (CSUWN) project, various livelihood and conservation interventions have been adopted particularly to prevent movement of domestic buffalo population into KTWR (Khatri et al. 2012). In addition, there is legal provision by KTWR office over the gathering of forest products like; fuelwood, fodder and grass in seasonal basis with the aim to reduce illegal collection (Khatri et al. 2010). Further, to provide sufficient forage and wallowing locations to guarantee the vitality and ecological integrity of WWB population, the WWB Conservation Action Plan for Nepal has emphasized to expand the habitat of KTWR (DNPWC 2020). Likewise, in every two years, KTWR undertakes a census of wild buffalo to analyze their population dynamics (Khadka 2018).

\section{CONCLUSION}

This study concluded that WWB mostly preferred the habitats within the distance of $500 \mathrm{~m}$ from the water sources, crown cover less than $25 \%$ and ground cover more than $75 \%$. Imperata cylindrica, Cynodon dactylon, and Sacharrum spontaneum were the most preferred grass species whereas Phyllanthus emblica and Acacia catechu were the most preferred tree species. However, majority of the shrub species, which have weed characteristics, were avoided. Overgrazing and cross breeding with domestic buffalo were the critical surviving threats to WWB in KTWR. As the last remaining population of WWB is experiencing several threats, different conservation interventions are required to secure the wild population. Our study recommends for strict prohibition of the livestock grazing inside the park, conservation of grass species such as Imperata cylindrica, Saccharum spontaneum, and Typha elephentina should be encouraged and effective management plan for controlling the spread of invasive plant species such as Chromoleana odorata, Eupatorium adenophorum, Lantana camara, and Mikania micrantha should be carried out immediately. Additionally, there is an urgent need to establish veterinary clinic, animal orphanages and proper service of rescue to control vulnerability of wild animals by flood and spreading of communicable diseases.

\section{REFERENCES}

Adhikari, K. (1999). An assessment on crop damage by wild buffalo in the eastern part of Koshi Tappu Wildlife Reserve. A M.Sc. thesis submitted to T.U., Central Department of Zoology Kathmandu, Nepal, 56pp.

Adhikari, K. (2006). Buffer zone management at Koshi Tappu Wildlife Reserve. A M.Sc. thesis submitted to T.U., Central Department of Zoology, Kathmandu, Nepal, 63pp.

Aryal, A., T.K. Shrestha, A. Ram, W. Frey, C. Groves, H. Hemmer, M. Dhakal, R.K. Koirala, J.T. Heinen \& D. Raubenheimer (2011). A call to save the wild water buffalo (Bubalus arnee) in Nepal. International Journal of Conservation Science 2: 261-268. 
Amin, R., H.S. Baral, B.R. Lamichhane, L.P. Poudyal, S. Lee, S.R. Jnawali, K.P. Acharya, G.P. Upadhayaya, M.B. Pandey, R. Shrestha, D. Joshi, J. Griffiths, A.P. Khatiwada \& N. Subedi (2018). The status of Nepal's mammals. Journal of Threatened Taxa 10(3): 1136111378. https://doi.org/10.11609/jott.3712.10.3.11361-11378

Baral, H.S. \& K. Shah (2008). Wild mammals of Nepal. Himalayan Nature, Kathmandu Nepal, 188pp.

Bolton, M. (1975). Royal Chitwan National Park Management Plan 1975-1979. UNDP/FAO. http://www.iucn.org/dbtw-wpd/edocs/ Bios-Cons-NatPro-541.35-008.pdf

Chettri, N., K. Uddin, S. Chaudhary \& E. Sharma (2013). Linking spatial-temporal land cover change to biodiversity conservation in the Koshi Tappu Wildlife Reserve, Nepal. Diversity 5: 335-351. https://doi.org/10.3390/d5020335

Chhetri, N.B., B. Dhami, B. Neupane, B.M. Sadadev \& N. Thapa (2020) Distributional evidence and threats to cheer pheasant (Catreus wallichii) in Annapurna Conservation Area, Nepal. Nepalese Journal of Zoology 4(2): 140-146. https://doi.org/10.3126/njz.v4i2.33906

CITES (2017). Appendices I, II and III, Convention on International Trade in Endangered Species of Wild Fauna and Flora (CITES), Geneva, Switzerland, 69pp.

Dahmer, T.D. (1978). Status and ecology of the wild Asian buffalo (Bubalus arnee) in Nepal. M.Sc. Thesis, University of Montana, Missoula, USA, 95pp. https://scholarworks.umt.edu/etd/6530

DNPWC (2020). Wild Water Buffalo (Bubalus arnee) Conservation Action Plan for Nepal (2020-2024), Department of National Parks and Wildlife Conservation, Babarmahal, Kathmandu, Nepal, 56pp. http://www.dnpwc.gov.np/media/publication/Arna_Conservation_ Action_Plan.pdf

DNPWC (2021). Press Release of Arna Census in KoshiTappu Wildlife Reserve. http://www.dnpwc.gov.np/media/files/

Flamand, J.R.B., D. Vankan, K.P. Gairhe, H. Duong \& J.S.F. Barker (2003). Genetic identification of wild Asian water buffalo in Nepal. Animal Conservation 6(3): 265-270.

GoN (1973). National Parks and Wildlife Conservation Act. Government of Nepal, Nepal Law Commission, Nepal, 15pp.

Groves, C.P. (1981). Systematic relationships in the bovini (Artiodactyla, Bovidae). Journal of Zoological Systematics and Evolutionary Research 19: 264-278. https://doi.org/10.1111/j.1439-0469.1981. tb00243.x

Heinen, J.T. \& P.K. Paudel (2015). On the translocation of wild Asian buffalo Bubalis arnee in Nepal: Are feral backcrosses worth conserving? Conservation Science 3: 11-21.

Heinen, J.T. \& G.R. Singh (2001). A census and some management implication for wild buffalo (Bubalus arnee) in Nepal. Biological Conservation 101: 391-394. https://doi.org/10.1016/S0006 3207(01)00078-7

Heinen, J.T. \& R.C. Kandel (2006). Threats to a small population: a census and conservation action plan for wild buffalo in Nepal. Oryx 40: 324-330. https://doi.org/10.1017/S0030605306000755

Heinen, J.T. (1993). Population viability and management recommendation for wild water buffalo Bubalus arnee in Kosh Tappu Wildlife Reserve, Nepal. Biological Conservation: 65(1): 2934. https://doi.org/10.1016/0006-3207(93)90193-5

Heinen, J.T. (2001). A translocaton proposal for Wild Bufalo (Bubalus bubalis) in Nepal: recommended management action in the face of uncertainty for a critically endangered species. Tiger Paper 28(3): $1-8$.

IUCN (1990). Directory of wetlands of international importance. Ramsar Convention Bureau, Gland, Switzerland, 516pp.

Ivlev, V.S. (1961). Experimental ecology of the feeding of fishes. Yale University Press, New Haven, CT, 302pp.

Jnawali, S.R., H.S. Baral, S. Lee, N. Subedi, K.P. Acharya, G.P. Upadhaya, M. Pandey, R. Shrestha, D. Joshi, B.R. Lamichhane, J. Friffiths \& A.P. Khatiwada (2011). The Status of Nepal's Mammals: The National Red List Series. Department of National Parks and Wildlife Conservation, Kathmandu, Nepal, 266pp.

Joshi, G., B. Neupane, D. Dahal, S. Shrestha, P. Dhakal, C.M.B. Jandug $\&$ D. Gautam (2020). Assessment of human-wildlife conflict in Kailali district of Nepal. Journal of Animal Diversity 2(3): 24-36. https:// doi.org/10.29252/JAD.2020.2.3.5

Kafle, K., D.R. Thanet, P. Poudel, D. Gautam, G. Thapa \& P. Bhatt (2020). Status and conservation threats to large mammals of the Laljhadi Mohana Biological Corridor, Nepal. Journal of Animal Diversity 2(2): 16-33. https://doi.org/10.29252/JAD.2020.2.2.3

Kaul, R., A.C. Williams, K. Rithe, R. Steinmetz \& R. Mishra (2019). Bubalus arnee. The IUCN Red List of Threatened Species 2019: e.T3129A46364616, 24pp. Downloaded on 24 June 2021. https:// doi.org/10.2305/IUCN.UK.2019-1.RLTS.T3129A46364616.en

Khadka, A. (2018). Koshi Tappu to take census of wild buffaloes. https://myrepublica.nagariknetwork.com/news/koshi-tappu-totake-census-of-wild-buffaloes/ Downloaded on 24 June 2021.

Khatri, T. B., D.N. Shah, R.D.T. Shah \& N. Mishra (2010). Biodiversity of Koshi Tappu Wildlife Reserve: a post flood assessment. Journal of Wetlands Ecology 4: 69-82.

Khatri, T.B., D.N. Shah \& N. Mishra (2012). Wild water buffalo Bubalus arnee in Koshi Tappu Wildlife Reserve, Nepal: status, population and conservation importance. Journal of Threatened Taxa 4: 3294-3301. https://doi.org/10.11609/JoTT.o2990.3294-301

KTWR (2018). Koshi Tappu Wildlife Reserve and Its Buffer Zone Management Plan (2074/75-2078/79) Koshi Tappu Wildlife Reserve Office, Paschim Kushaha, Sunsari, Nepal, 214pp. http://dnpwc.gov. np/media/publication/Koshi_Tappu_WR_Management_Plan.pdf

Lama, R.C. (2013). Status, distribution and food preference of Wild Water Buffalo on Koshi Tappu Wildlife Reserve.

Neupane, B., B.K. Singh, P. Poudel, S. Panthi \& N.D. Khatri (2020). Habitat occupancy and threat assessment of gharial (Gavialis gangeticus) in the Rapti River, Nepal. Global Ecology and Conservation, 24: e01270. https://doi.org/10.1016/j.gecco.2020. e01270

Neupane, B., N.B. Chhetri \& B. Dhami (2021). Habitat selection of Himalayan Musk Deer Moschus leucogaster (Mammalia: Artiodactyla: Moschidae) with respect to biophysical attributes in Annapurna Conservation Area of Nepal. Journal of Threatened Taxa 13(7):18703-18712. https://doi.org/10.11609/ jott.6725.13.7.18703-18712

NHWAP (2015). Threat Assessment Instructions for Ranking Threats to Species and Habitats. New Hampshire Wildlife Action Plan Appendix E-1, 1-16

Nicholson, E., D.A. Keith \& D.S. Wilcove (2009). Assessing the threat status of ecological communities, Conservation Biology, 23: 259274. https://doi.org/10.1111/j.1523-1739.2008.01158.x

Nowak, R.M. (1999). Walker's mammals of the World, $6^{\text {th }}$ Edition. Johns Hopkins University Press, Baltimore, 1166-1170pp.

Parihar, J.S., P.C. Kotwal, S. Panigrahi \& N. Chaturvedi (1986). Study of wildlife habitat using high-resolution space photographs: a case study of Kanha National Park. ISRO-SP-17-86, special publication of Indian Space Research Organization, Space Applications Centre, Ahmedabad, 65-82pp.

Ram, A. \& K. P. Sharma (2011). Status, distribution, threat and habitat pattern assessment of Asiatic wild water buffalo in Koshi Tappu Wildlife Reserve. Eastern Nepal 9: 12-16.

Roth, J. (2004). "Bubalus bubalis" (on-line), Animal diversity web. Accessed 17 September 2020 at https://animaldiversity.org/ accounts/Bubalus_bubalis/

Sah, J.P. (1997). Koshi Wetlands: Nepal's RAMSAR SITE. IUCN Nepal. 254pp.

Siwakoti, M. (2009). An overview of floral diversity in wetland of terai Region of Nepal. Our Nature 4: 83-90.

Shah, R., S. Tripathi \& B. Bhatta (2017). Translocation of Wild Asian Buffalo (Bubalus arnee): a way forward to conservation in Nepal. In: Proceedings of the International Buffalo Symposium, 175-178pp.

Shrestha, B.P. \& B. Pantha (Eds.) (2018). Protected areas of Nepal (in Nepali). Department of National Parks and Wildlife Conservation, Government of Nepal, Kathmandu, Nepal, 104pp.

Shrestha, T.K. (1997). Mammals of Nepal with reference of those of India, Bangladesh, Bhutan and Pakistan. RK Printers, Kathmandu, Nepal, 371pp. 
Singh, A. (2015). Vanishing herds of wild water buffalo. Science India, September 2015, 4pp.

Thapa, R., B. Neupane, S. Ranabhat, M. Poudel \& S. Panthi (2020). Habitat suitability of wild water buffalo (Bubalus arnee) in Babai flood plain of Bardia National Park, Nepal. Global Ecology and Conservation, 23, e01172. https://doi.org/10.1016/j.gecco.2020. e01172

TNC (THE NATURE CONSERVANCY) (2007). Conservation Action Planning Handbook: Developing Strategies, Taking Actions and Measuring Success at any Scale. The Nature Conservancy, Arlington, USA, 127pp. https://www.conservationgateway.org/Documents/ Cap\%20Handbook_June2007.pdf
WWF (2007). Resources for implementing the World Wildlife Fund (WWF) project and program standards. Step 1.4. Define situation analysis. 15pp. https://C:/Users/DELL/Downloads/1_4_situation_ analysis_2007_02_19.pdf

Yonzon, P.B. \& M.L. Hunter (1989). Ecological study of the Red Panda in the Nepal-Himalayas. In: Glatson, A.R., (Ed.). Red Panda Biology. Academic Publication, The Hauge, Netherlands, 1-8.

Zobel, D.B., M.J. Behan, P.K. Jha \& U.K.R. Yadav (1987). A practical manual for ecology. Ratna Book Distributors, Kathmandu, Nepal, $149 p$.

Wilio 

Dr. Albert G. Orr, Griffith University, Nathan, Australia

Dr. Sameer Padhye, Katholieke Universiteit Leuven, Belgium

Dr. Nancy van der Poorten, Toronto, Canada

Dr. Kareen Schnabel, NIWA, Wellington, New Zealand

Dr. R.M. Sharma, (Retd.) Scientist, Zoological Survey of India, Pune, India

Dr. Manju Siliwal, WILD, Coimbatore, Tamil Nadu, India

Dr. G.P. Sinha, Botanical Survey of India, Allahabad, India

Dr. K.A. Subramanian, Zoological Survey of India, New Alipore, Kolkata, India

Dr. P.M. Sureshan, Zoological Survey of India, Kozhikode, Kerala, India

Dr. R. Varatharajan, Manipur University, Imphal, Manipur, India

Dr. Eduard Vives, Museu de Ciències Naturals de Barcelona, Terrassa, Spain

Dr. James Young, Hong Kong Lepidopterists' Society, Hong Kong

Dr. R. Sundararaj, Institute of Wood Science \& Technology, Bengaluru, India

Dr. M. Nithyanandan, Environmental Department, La Ala Al Kuwait Real Estate. Co. K.S.C., Kuwait

Dr. Himender Bharti, Punjabi University, Punjab, India

Mr. Purnendu Roy, London, UK

Dr. Saito Motoki, The Butterfly Society of Japan, Tokyo, Japan

Dr. Sanjay Sondhi, TITLI TRUST, Kalpavriksh, Dehradun, India

Dr. Nguyen Thi Phuong Lien, Vietnam Academy of Science and Technology, Hanoi, Vietnam

Dr. Nitin Kulkarni, Tropical Research Institute, Jabalpur, India

Dr. Robin Wen Jiang Ngiam, National Parks Board, Singapore

Dr. Lional Monod, Natural History Museum of Geneva, Genève, Switzerland.

Dr. Asheesh Shivam, Nehru Gram Bharti University, Allahabad, India

Dr. Rosana Moreira da Rocha, Universidade Federal do Paraná, Curitiba, Brasil

Dr. Kurt R. Arnold, North Dakota State University, Saxony, Germany

Dr. James M. Carpenter, American Museum of Natural History, New York, USA

Dr. David M. Claborn, Missouri State University, Springfield, USA

Dr. Kareen Schnabel, Marine Biologist, Wellington, New Zealand

Dr. Amazonas Chagas Júnior, Universidade Federal de Mato Grosso, Cuiabá, Brasil

Mr. Monsoon Jyoti Gogoi, Assam University, Silchar, Assam, India

Dr. Heo Chong Chin, Universiti Teknologi MARA (UiTM), Selangor, Malaysia

Dr. R.J. Shiel, University of Adelaide, SA 5005, Australia

Dr. Siddharth Kulkarni, The George Washington University, Washington, USA

Dr. Priyadarsanan Dharma Rajan, ATREE, Bengaluru, India

Dr. Phil Alderslade, CSIRO Marine And Atmospheric Research, Hobart, Australia

Dr. John E.N. Veron, Coral Reef Research, Townsville, Australia

Dr. Daniel Whitmore, State Museum of Natural History Stuttgart, Rosenstein, Germany.

Dr. Yu-Feng Hsu, National Taiwan Normal University, Taipei City, Taiwan

Dr. Keith V. Wolfe, Antioch, California, USA

Dr. Siddharth Kulkarni, The Hormiga Lab, The George Washington University, Washington,

D.C., USA

Dr. Tomas Ditrich, Faculty of Education, University of South Bohemia in Ceske

Budejovice, Czech Republic

Dr. Mihaly Foldvari, Natural History Museum, University of Oslo, Norway

Dr. V.P. Uniyal, Wildlife Institute of India, Dehradun, Uttarakhand 248001, India

Dr. John T.D. Caleb, Zoological Survey of India, Kolkata, West Bengal, India

Dr. Priyadarsanan Dharma Rajan, Ashoka Trust for Research in Ecology and the Environment (ATREE), Royal Enclave, Bangalore, Karnataka, India

\section{Fishes}

Dr. Neelesh Dahanukar, IISER, Pune, Maharashtra, India

Dr. Topiltzin Contreras MacBeath, Universidad Autónoma del estado de Morelos, México

Dr. Heok Hee Ng, National University of Singapore, Science Drive, Singapore

Dr. Rajeev Raghavan, St. Albert's College, Kochi, Kerala, India

Dr. Robert D. Sluka, Chiltern Gateway Project, A Rocha UK, Southall, Middlesex, UK

Dr. E. Vivekanandan, Central Marine Fisheries Research Institute, Chennai, India

Dr. Davor Zanella, University of Zagreb, Zagreb, Croatia

Dr. A. Biju Kumar, University of Kerala, Thiruvananthapuram, Kerala, India

Dr. Akhilesh K.V., ICAR-Central Marine Fisheries Research Institute, Mumbai Research

Centre, Mumbai, Maharashtra, India

Dr. J.A. Johnson, Wildlife Institute of India, Dehradun, Uttarakhand, India

\section{Amphibians}

Dr. Sushil K. Dutta, Indian Institute of Science, Bengaluru, Karnataka, India

Dr. Annemarie Ohler, Muséum national d'Histoire naturelle, Paris, France

\section{Reptiles}

Dr. Gernot Vogel, Heidelberg, Germany

Dr. Raju Vyas, Vadodara, Gujarat, India

Dr. Pritpal S. Soorae, Environment Agency, Abu Dubai, UAE.

Prof. Dr. Wayne J. Fuller, Near East University, Mersin, Turkey

Prof. Chandrashekher U. Rivonker, Goa University, Taleigao Plateau, Goa. India

Dr. S.R. Ganesh, Chennai Snake Park, Chennai, Tamil Nadu, India

Dr. Himansu Sekhar Das, Terrestrial \& Marine Biodiversity, Abu Dhabi, UAE
Birds

Dr. Hem Sagar Baral, Charles Sturt University, NSW Australia

Dr. Chris Bowden, Royal Society for the Protection of Birds, Sandy, UK

Dr. Priya Davidar, Pondicherry University, Kalapet, Puducherry, India

Dr. J.W. Duckworth, IUCN SSC, Bath, UK

Dr. Rajah Jayapal, SACON, Coimbatore, Tamil Nadu, India

Dr. Rajiv S. Kalsi, M.L.N. College, Yamuna Nagar, Haryana, India

Dr. V. Santharam, Rishi Valley Education Centre, Chittoor Dt., Andhra Pradesh, India

Dr. S. Balachandran, Bombay Natural History Society, Mumbai, India

Mr. J. Praveen, Bengaluru, India

Dr. C. Srinivasulu, Osmania University, Hyderabad, India

Dr. K.S. Gopi Sundar, International Crane Foundation, Baraboo, USA

Dr. Gombobaatar Sundev, Professor of Ornithology, Ulaanbaatar, Mongolia

Prof. Reuven Yosef, International Birding \& Research Centre, Eilat, Israel

Dr. Taej Mundkur, Wetlands International, Wageningen, The Netherlands

Dr. Carol Inskipp, Bishop Auckland Co., Durham, UK

Dr. Tim Inskipp, Bishop Auckland Co, Durham, UK

Dr. V. Gokula, National College, Tiruchirappalli, Tamil Nadu, India

Dr. Arkady Lelej, Russian Academy of Sciences, Vladivostok, Russia

Dr. Simon Dowell, Science Director, Chester Zoo, UK

Dr. Mário Gabriel Santiago dos Santos, Universidade de Trás-os-Montes e Alto Douro,

Quinta de Prados, Vila Real, Portugal

Dr. Grant Connette, Smithsonian Institution, Royal, VA, USA

Dr. M. Zafar-ul Islam, Prince Saud Al Faisal Wildlife Research Center, Taif, Saudi Arabia

Mammals

Dr. Giovanni Amori, CNR - Institute of Ecosystem Studies, Rome, Italy

Dr. Anwaruddin Chowdhury, Guwahati, India

Dr. David Mallon, Zoological Society of London, UK

Dr. Shomita Mukherjee, SACON, Coimbatore, Tamil Nadu, India

Dr. Angie Appel, Wild Cat Network, Germany

Dr. P.O. Nameer, Kerala Agricultural University, Thrissur, Kerala, India

Dr. Ian Redmond, UNEP Convention on Migratory Species, Lansdown, UK

Dr. Heidi S. Riddle, Riddle's Elephant and Wildlife Sanctuary, Arkansas, USA

Dr. Karin Schwartz, George Mason University, Fairfax, Virginia.

Dr. Lala A.K. Singh, Bhubaneswar, Orissa, India

Dr. Mewa Singh, Mysore University, Mysore, India

Dr. Paul Racey, University of Exeter, Devon, UK

Dr. Honnavalli N. Kumara, SACON, Anaikatty P.O., Coimbatore, Tamil Nadu, India

Dr. Nishith Dharaiya, HNG University, Patan, Gujarat, India

Dr. Spartaco Gippoliti, Socio Onorario Società Italiana per la Storia della Fauna "Giuseppe

Altobello", Rome, Italy

Dr. Justus Joshua, Green Future Foundation, Tiruchirapalli, Tamil Nadu, India

Dr. H. Raghuram, The American College, Madurai, Tamil Nadu, India

Dr. Paul Bates, Harison Institute, Kent, UK

Dr. Jim Sanderson, Small Wild Cat Conservation Foundation, Hartford, USA

Dr. Dan Challender, University of Kent, Canterbury, UK

Dr. David Mallon, Manchester Metropolitan University, Derbyshire, UK

Dr. Brian L. Cypher, California State University-Stanislaus, Bakersfield, CA

Dr. S.S. Talmale, Zoological Survey of India, Pune, Maharashtra, India

Prof. Karan Bahadur Shah, Budhanilakantha Municipality, Kathmandu, Nepal

Dr. Susan Cheyne, Borneo Nature Foundation International, Palangkaraja, Indonesia

Dr. Hemanta Kafley, Wildlife Sciences, Tarleton State University, Texas, USA

\section{Other Disciplines}

Dr. Aniruddha Belsare, Columbia MO 65203, USA (Veterinary)

Dr. Mandar S. Paingankar, University of Pune, Pune, Maharashtra, India (Molecular)

Dr. Jack Tordoff, Critical Ecosystem Partnership Fund, Arlington, USA (Communities)

Dr. Ulrike Streicher, University of Oregon, Eugene, USA (Veterinary)

Dr. Hari Balasubramanian, EcoAdvisors, Nova Scotia, Canada (Communities)

Dr. Rayanna Hellem Santos Bezerra, Universidade Federal de Sergipe, São Cristóvão, Brazil

Dr. Jamie R. Wood, Landcare Research, Canterbury, New Zealand

Dr. Wendy Collinson-Jonker, Endangered Wildlife Trust, Gauteng, South Africa

Dr. Rajeshkumar G. Jani, Anand Agricultural University, Anand, Gujarat, India

Dr. O.N. Tiwari, Senior Scientist, ICAR-Indian Agricultural Research Institute (IARI), New

Delhi, India

Dr. L.D. Singla, Guru Angad Dev Veterinary and Animal Sciences University, Ludhiana, India

Dr. Rupika S. Rajakaruna, University of Peradeniya, Peradeniya, Sri Lanka

Dr. Bahar Baviskar, Wild-CER, Nagpur, Maharashtra 440013, India

Reviewers 2018-2020

Due to pausity of space, the list of reviewers for 2018-2020 is available online.
The opinions expressed by the authors do not reflect the views of the Journal of Threatened Taxa, Wildlife Information Liaison Development Society, Zoo Outreach Organization, or any of the partners. The journal, the publisher, the host, and the partners are not responsible for the accuracy of the political boundaries shown in the maps by the authors.

\footnotetext{
Print copies of the Journal are available at cost. Write to:

The Managing Editor, JoTT,

c/o Wildlife Information Liaison Development Society,

No. 12, Thiruvannamalai Nagar, Saravanampatti - Kalapatti Road,

Saravanampatti, Coimbatore, Tamil Nadu 641035, India

ravi@threatenedtaxa.org
} 


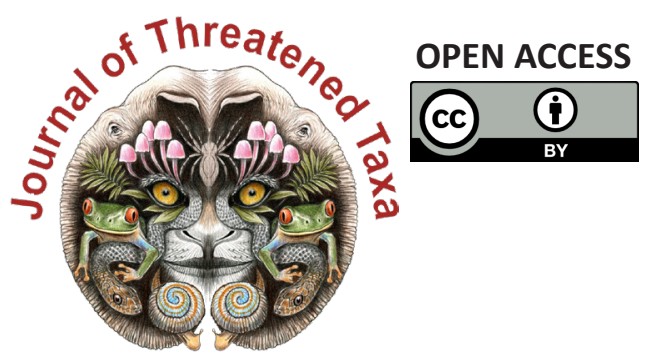

www.threatenedtaxa.org

The Journal of Threatened Taxa (JoTT) is dedicated to building evidence for conservation globally by publishing peer-reviewed articles online every month at a reasonably rapid rate at www.threatenedtaxa.org. All articles published in JoTT are registered under Creative Commons Attribution 4.0 International License unless otherwise mentioned. JoTT allows allows unrestricted use, reproduction, and distribution of articles in any medium by providing adequate credit to the author(s) and the source of publication.

\section{ISSN $0974-7907$ (Online) | ISSN $0974-7893$ (Print)}

\section{October 2021 | Vol. 13 | No. 12 | Pages: 19675-19886 \\ Date of Publication: 26 October 2021 (Online \& Print) DOI: 10.11609/jott.2021.13.12.19675-19886}

Articles

Roosting habits and habitats of the Indian Flying Fox Pteropus medius Temminck, 1825 in the northern districts of Tamil Nadu, India

- M. Pandian \& S. Suresh, Pp. 19675-19688

Diversity and distribution of avifauna at Warathenna-Hakkinda Environmental Protection Area in Kandy, Sri Lanka

- Dinelka Thilakarathne, Tithira Lakkana, Gayan Hirimuthugoda, Chaminda Wijesundara \& Shalika Kumburegama, Pp. 19689-19701

Grass species composition in tropical forest of southern India

- M. Ashokkumar, S. Swaminathan \& R. Nagarajan, Pp. 19702-19713

\section{Communications}

Habitat use and conservation threats to Wild Water Buffalo Bubalus arnee (Mammalia: Artiodactyla: Bovidae) in Koshi Tappu Wildlife Reserve, Nepal

- Reeta Khulal, Bijaya Neupane, Bijaya Dhami, Siddhartha Regmi, Ganesh Prasad Tiwari \& Manita Parajuli, Pp. 19714-19724

Get my head around owls: people perception and knowledge about owls of Andaman Islands

- Shanmugavel Sureshmarimuthu, Santhanakrishnan Babu, Nagaraj Rajeshkumar \& Honnavalli Nagaraj Kumara, Pp. 19725-19732

Abundance and diversity of threatened birds in Nangal Wetland, Punjab, India - Rajwinder Kaur \& Onkar Singh Brraich, Pp. 19733-19742

Evaluation of fish diversity and abundance in the Kabul River with comparisons between reaches above and below Kabul City, Afghanistan

- Ugyen Kelzang, Ahmad Farid Habibi \& Ryan J. Thoni, Pp. 19743-19752

New record of Myrmarachne melanocephala MacLeay, 1839 (Araneae: Salticidae) from Jharkhand, India and biogeographical implications of the co-occurrence of its ant model Tetraponera rufonigra Jerdon, 1851

- Rahul Kumar, Mirtunjay Sharma \& Ajay Kumar Sharma, Pp. 19753-19761

Diversity of spiders (Arachnida: Araneae) and the impact of pruning in Indian sandalwood plantations from Karnataka, India

-S. Padma 1 \& R. Sundararaj, Pp. 19762-19772

New records of cheilostome Bryozoa from the eastern coast of India encrusting on the exoskeleton of live horseshoe crabs of Indian Sundarbans

- Swati Das, Maria Susan Sanjay, Basudev Tripathy, C. Venkatraman \& K.A. Subramanian, Pp. 19773-19780

On the pteridophytes of Bherjan-Borajan-Padumoni Wildlife Sanctuary, Assam, India - Pranjal Borah \& Jayanta Barukial, Pp. 19781-19790

Population status of Heritiera fomes Buch.-Ham., a threatened species from Mahanadi Mangrove Wetland, India

- Sudam Charan Sahu, Manas Ranjan Mohanta \& N.H. Ravindranath, Pp. 19791-19798

Additions to the lichenized and lichenicolous fungi of Jammu \& Kashmir from Kishtwar High Altitude National Park

- Vishal Kumar, Yash Pal Sharma, Siljo Joseph, Roshinikumar Ngangom \& Sanjeeva Nayaka, Pp. 19799-19807

\section{Short Communications}

Is release of rehabilitated wildlife with embedded lead ammunition advisable? Plumbism in a Jaguar Panthera Onca (Mammalia: Carnivora: Felidae), survivor of gunshot wounds - Eduardo A. Díaz, Carolina Sáenz, E. Santiago Jiménez, David A. Egas \& Kelly Swing, Pp. 19808-19812

New record of the Sewing Needle Zipper Loach Paracanthocobitis linypha Singer \& Page, 2015 (Teleostei: Cypriniformes: Nemacheilidae) from the Chindwin drainage of Manipur, India

- Yumnam Rameshori, Yengkhom Chinglemba \& Waikhom Vishwanath, Pp. 19813-19817

Field identification characters to diagnose Microhyla mukhlesuri from closely related M. mymensinghensis (Amphibia: Microhylidae) and range extension of $M$. mukhlesuri up to West Bengal State, India

- Suman Pratihar \& Kaushik Deuti, Pp. 19818-19823
First report of Scipinia horrida (Stål) (Heteroptera: Reduviidae) from Assam, with comments on related genus Irantha Stål

- Anjana Singha Naorem, Santana Saikia, Anandita Buragohain, Rubina Azmeera Begum, Swapnil S. Boyane \& Hemant V. Ghate, Pp. 19824-19830

Flesh fly (Diptera: Sarcophagidae): male terminalia, diversity and expanded geographical distribution from India

- Kanholi Sreejith, Shuvra Kanti Sinha, Santanu Mahato \& Edamana Pushpalatha, Pp. 1983119836

Checklist of moths (Heterocera) of Tadong, Sikkim, India

- Prayash Chettri, Yuki Matsui, Hideshi Naka \& Archana Tiwari, Pp. 19837-19848

New distribution records of Begonia L., B. murina Craib and B. poilanei Kiew (Begoniaceae: Cucurbitales) for Laos

- Phongphayboun Phonepaseuth, Phetlasy Souladeth, Soulivanh Lanorsavanh, Shuichiro Tagane, Thyraphon Vongthavone \& Keooudone Souvannakhoummane Pp. 19849-19854

Notes

A recent sighting of the Stripe-backed Weasel Mustela strigidorsa (Mammalia: Carnivora: Mustelidae) in Hkakabo Razi Landscape, Myanmar

- Sai Sein Lin Oo, Tun Tun, Kyaw Myo Naing \& Paul Jeremy James Bates, Pp. 19855-19859

Are the uplifted reef beds in North Andaman letting nesting Olive Ridley Sea Turtle Lepidochelys olivacea stranded?

- Nehru Prabakaran, Anoop Raj Singh \& Vedagiri Thirumurugan, Pp. 19860-19863

First record of the orb-weaving spider Araneus tubabdominus Zhu \& Zhang, 1993 (Araneae: Araneidae) from India

- Souvik Sen, John T.D. Caleb \& Shelley Acharya, Pp. 19864-19866

The genus Catapiestus Perty, 1831 (Coleoptera: Tenebrionidae: Cnodalonini) from Arunachal Pradesh with one new record to India

- V.D. Hegde \& Sarita Yadav, Pp. 19867-19869

Rediscovery and extended distribution of Indigofera santapaui Sanjappa (Leguminosae: Papilionoideae) from the states of Maharashtra and Gujarat, India

- Kumar Vinod Chhotupuri Gosavi, Sanjay Gajanan Auti, Sharad Suresh Kambale \& Munivenkatappa Sanjappa, Pp. 19870-19873

Additional distribution records of Ceropegia anjanerica, an endemic and 'Endangered' lantern flower of the northern Western Ghats, India

- Samir Shrikant Maity, Ajay Natha Gangurde, Sharad Suresh Kambale, Avinash Ramchandra Gholave, Avinash Asraji Adsul, Ganesh Babaso Pawar \& Kumar Vinod Chhotupuri Gosavi, Pp. 19874-19877

Notes on the extended distribution of Impatiens megamalayana, a recently described balsam in Western Ghats, India

- Anoop P. Balan \& A.J. Robi, Pp. 19878-19883

Book Review

A look over on the scented tree of India (Santalum album - S. Suresh Ramanan \& A. Arunachalam, Pp. 19884-19886
Publisher \& Host
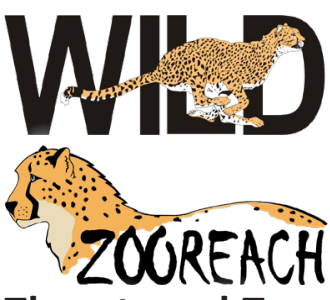

Threatened Taxa 